\title{
Laser-triggered combination therapy by iron sulfide-doxorubicin@functionalized nanozymes for breast cancer therapy
}

Shipeng Ning ${ }^{1 \dagger}$, Yang Zheng ${ }^{1 \dagger}$, Kun QiaO ${ }^{2}$, Guozheng $\mathrm{Li}^{2}$, Qian Bai ${ }^{3^{*}}$ and Shouping $\mathrm{Xu}^{2^{*}}$

\begin{abstract}
Background: The use of magnetic nanozymes (NZs) with the ability to synchronize gas therapy through photodynamic and chemotherapy in the treatment of breast cancer has received much attention.

Results: Hence, in this study, we designed a bovine lactoferrin-coated iron sulfide NZs containing doxorubicin (abbreviated as: FeS-Dox@bLf NZs) by wet-chemical synthesis method. Then, the physicochemical characteristics of synthesized NZs were explored by several methods. Also, the level of Fe ${ }^{2+}, \mathrm{H}_{2} \mathrm{~S}$ and Dox releases from FeS-Dox@Lf NZs. Also, the cytotoxic effects of FeS-Dox@Lf NZs were investigated by cellular assays. After intravenous injections of NZs and laser irradiation, significant effects of FeS-Dox@Lf NZs on mice weight and tumor status were observed. Afterwards, not only the distribution of Dox in the body was examined by fluorescent, but also the time of Fe clearance and the amount of Dox and Fe retention in vital tissues were determined. The findings confirm that FeS-Dox@Lf $\mathrm{NZs}$, in addition to targeted drug distribution in tumor tissue, resulted in superior therapeutic performance compared to free Dox due to reduced Dox side effects in vital tissues, and increased level of free radicals in 4T1 cells.
\end{abstract}

Conclusion: Overall, FeS-Dox@Lf NZs with the ability to synchronize chemotherapy and gas therapy raised hopes for more effective treatment of breast cancer.

Keywords: Breast cancer, Gas therapy, Chemotherapy, Nanozyme, Fenton reaction

\section{Introduction}

Breast cancer is one of the most challenging diseases in women that the use of new techniques based on nanoplatforms with less invasiveness has increased the hopes of treatment $[1,2]$. In this regard, the use of magnetic nanoparticles (NPs) with enzyme-like behaviors for producing radicals $[3,4]$ along with the provision of imaging [5], photothermal therapy (PTT) [6], photodynamic therapy (PDT) [7] and chemotherapy [8] have

\footnotetext{
*Correspondence: baiqian@zzu.edu.cn; Shoupingxu@hrbmu.edu.cn

${ }^{\dagger}$ Shipeng Ning and Yang Zheng contributed equally to this study

2 Department of Breast Surgery, Harbin Medical University Cancer Hospital, 150 haping Road, Nangang District, Harbin 150000, China

${ }^{3}$ Department of Anesthesiology, The Second Affiliated Hospital of Zhengzhou University, Zhengzhou, People's Republic of China

Full list of author information is available at the end of the article
}

received much attention. The enzymatic-like activity of magnetic NPs induces apoptosis by persuading radicals in cancerous cells through damage of fat, protein and DNA $[9,10]$. For this purpose, several papers have been published based on iron nanozymes (Fe NZs) that show the formation of radicals through the Fenton reaction on hydrogen peroxide $\left(\mathrm{H}_{2} \mathrm{O}_{2}\right)$ inside and outside of cells [11-13]. However, the results demonstrate that the amount of $\mathrm{H}_{2} \mathrm{O}_{2}$ in cancerous cells, especially breast cancer, is not high enough to generate reactive oxygen species (ROS) by Fe NZs $[4,14,15]$. On the other hand, several results exhibit that cancerous cells use enzymatic and non-enzymatic antioxidant defense systems to inhibit the generation and accumulation of radicals $[16,17]$. Therefore, development of free radicals-based original author(s) and the source, provide a link to the Creative Commons licence, and indicate if changes were made. The images or other third party material in this article are included in the article's Creative Commons licence, unless indicated otherwise in a credit line to the material. If material is not included in the article's Creative Commons licence and your intended use is not permitted by statutory regulation or exceeds the permitted use, you will need to obtain permission directly from the copyright holder. To view a copy of this licence, visit http://creativecommons.org/licenses/by/4.0/. The Creative Commons Public Domain Dedication waiver (http://creativeco mmons.org/publicdomain/zero/1.0/) applies to the data made available in this article, unless otherwise stated in a credit line to the data. 
therapeutic platforms to control breast cancer cells have received a great deal of interest, recently.

Gas therapy through hydrogen, nitric oxide (NO) and hydrogen sulfide $\left(\mathrm{H}_{2} \mathrm{~S}\right)$ are modern and effective methods in medical activities for antibacterial [18], cardiovascular [19], neurological [20], anti-inflammatory [21] and anti-cancer activities [22, 23]. Conventionally, $\mathrm{H}_{2} \mathrm{~S}$ and NO gases have been reported in the human body, especially in the mitochondria, which can enhance their use in medical practice [24]. The reports reveal that $\mathrm{H}_{2} \mathrm{~S}$ kills breast cancer cells by stopping the cell cycle through damage to mitochondria and miRNA [25, 26]. On the other hand, $\mathrm{H}_{2} \mathrm{~S}$ inhibits catalase activity dramatically [27]. Because, $\mathrm{H}_{2} \mathrm{~S}$ donors induce toxicity through the rapid release of gas, some bio-alternatives approaches are recommended.

Furthermore, the lack of a completely successful strategy in the application of iron sulfide (FeS) NZs, the use of anti-cancer drugs such as doxorubicin (Dox), and the formation of coatings on NZs to reduce toxicity and improve targeting can increase the likelihood of success. Despite the ambiguities in the use of Dox in the treatment of breast cancer, several reports indicate that Dox causes breast cancer cell death by increasing ROS and overexpression of Fass, Bax and caspase- 3 [6, $8,28,29]$. On the other hand, various results show that the challenge of Dox toxicity on heart cells $[8,30]$ and on the other hand the drug resistance of cancer cells by nanocarriers with bovine lactoferrin (bLf) coating is significantly reduced $[31,32]$.

In this study, not only the synthesis of FeS-Dox@bLf NZs was investigated to synchronize chemotherapy and gas therapy, but also the toxicity and drug loading along with the level of $\mathrm{H}_{2} \mathrm{~S}$ and radical release were investigated. Also, in this study, the condition of the tumor, the amount of Dox and Fe retention in non-target tissues, and possible damage in non-target tissues were investigated. In fact, we aimed to provide a biocompatible platform for integrating therapeutic activities with minimally invasive approach in order to reduce the therapeutic resistance of breast cancer cells and their effective treatment.

\section{Material and methods Materials}

$\mathrm{Fe}\left(\mathrm{NO}_{3}\right)_{3} \cdot 9 \mathrm{H}_{2} \mathrm{O}$, chloroacetic acid, $\mathrm{NaOH}$, thiourea, 1-ethyl-3-(3-dimethylaminopropyl) carbodiimide (EDC), $N$-hydroxysuccinimide (NHS), dimethyl sulfoxide (DMSO), methylene blue (MB), and polyvinylpyrrolidone were prepared from the Merck (Germany). Cell culture materials were obtained from Gibco (Scotland).

\section{Synthesis of FeS@bLf NZs}

Initially, a three-core Fe was provided to produce FeS NZs. In this regard, a chloroacetate solution produced from $\mathrm{ClCH}_{2} \mathrm{COOH}(5 \mathrm{~g}, 54 \mathrm{mmol})$ and $\mathrm{NaOH}(2.2 \mathrm{~g}$, $55 \mathrm{mmol}$ ) in $100 \mathrm{~mL}$ of water was gradually added to $11 \mathrm{~mL}$ of $\mathrm{Fe}\left(\mathrm{NO}_{3}\right)_{3} \cdot 9 \mathrm{H}_{2} \mathrm{O}(11 \mathrm{~g}, 27.5 \mathrm{mmol})$ solution. After $3 \mathrm{~h}$, the red solution was filtered and kept at $21^{\circ} \mathrm{C}$ for 2 weeks. Then, the precipitated red crystals were washed with cold methanol and air-dried. The resulting red crystals $(420 \mathrm{mg} ; 0.45 \mathrm{mmol}$ ) were dissolved in $35 \mathrm{~mL}$ of water, followed by addition of $10 \mathrm{~mL}$ of aqueous solution containing $110 \mathrm{mg}(1.45 \mathrm{mmol})$ of thiourea and $700 \mathrm{mg}$ of polyvinylpyrrolidone by stirring. Afterwards, the clear solution was kept into an autoclave with $150{ }^{\circ} \mathrm{C}$ (increase by $5{ }^{\circ} \mathrm{C}$ per min) for $14 \mathrm{~h}$. Finally, the $\mathrm{FeS} \mathrm{NZs}$ was gathered via centrifugation (7000 $\mathrm{g}$ in $10 \mathrm{~min}$ ), washed several times with methanol, and air-dried. The FeS NZs synthesis process was performed under oxygen-free conditions in a nitrogen atmosphere, as well as in oxygen-free water produced by boiling the solution and cooling it under a stream of free nitrogen.

Then, a mixture of $300 \mu \mathrm{L}$ of $15 \mathrm{mg} / \mathrm{mL}$ EDC, $300 \mu \mathrm{L}$ of $15 \mathrm{mg} / \mathrm{mL} \mathrm{NHS}$, and $10 \mu \mathrm{L}$ of $1 \mathrm{M} \mathrm{NaOH}$ were used to organize carboxyl linkers on the FeS NZs for creating bLf. In this field, $1 \mathrm{mg}$ of FeS NZs was sonicated for $20 \mathrm{~min}$ in $300 \mu \mathrm{L}$ of the solution prepared. Then, surplus EDC and NHS was removed using PD-10 column. Afterwards, a defined amount of bLf was added to the activated FeS NZs for $24 \mathrm{~h}$ at room temperature. Finally, centrifugation (5000g, at $5 \mathrm{~min}$ ) and DI water were applied to detach the FeS@bLf. After the production of FeS@bLf NZs, 3 mg of FeS@bLf NZs were mixed with $3 \mathrm{~mL}$ of DMSO solution containing $3 \mathrm{mg}$ of Dox for loading the Dox into the NZs. Then, the NZs were dried under vacuum for $24 \mathrm{~h}$. Ultimately, PBS was applied to wash the NZs 3 times to remove the discharged Dox via shaking for a $1 \mathrm{~min}$.

\section{Characterization of FeS-Dox@bLf NZs}

The FeS-Dox@bLf NZ morphology was considered using a scanning electron microscope (SEM, 250 FEG Quanta). As well, transmission electron microscope (TEM) image was provided on a high-resolution TEM (Carl Zeiss, Oberkochen, Germany) at an accelerating voltage of $200 \mathrm{kV}$. Moreover, the hydrodynamic size and zeta potential of FeS-Dox@bLf NZs were measured by Zetasizer Nano-ZS (Malvern, UK). $10 \mu \mathrm{L}$ of FeS-Dox@bLf NZs was dispersed in $10 \mathrm{mM}$ PBS solution. Furthermore, infrared spectra with a Nicolet model 759 FTIR spectrometer were evaluated in wavenumbers from 4000 to $500 \mathrm{~cm}^{-1}$ using FTIR spectroscopy (Perkin Elmer Inc., Wellesley, MA, USA). 


\section{Hydroxyl radical formation catalysed by FeS-Dox@bLf NZ}

The photocatalytic degradation of MB by FeS-Dox@ bLf $\mathrm{NZ}$ was performed at $22{ }^{\circ} \mathrm{C}$ using $40 \mathrm{~mL} \mathrm{MB}$ aqueous solution $\left(6 \times 10^{-6} \mathrm{M}\right)$ containing $30 \mathrm{mM} \mathrm{NaHCO}_{3}$ and $11 \mathrm{mM} \mathrm{H}_{2} \mathrm{O}_{2}$, and $20 \mathrm{mg}$ of FeS-Dox@bLf NZ with continuous stirring in a dark flask for $30 \mathrm{~min}$. Then, suspension was irradiated with the tungsten halogen lamp $(100 \mathrm{~W})$. During the determined time periods, $3 \mathrm{~mL}$ of the aliquot was removed from the mixture and centrifuged and the dye concentration was measured with an UV-Vis spectrophotometer.

\section{$\mathrm{Fe}^{+}, \mathrm{H}_{2} \mathrm{~S}$ and drug release}

To determine the level of $\mathrm{Fe}^{+}$released, $450 \mu \mathrm{L}$ of FeSDox@bLf NZ (6 mM) was added into a dialysis bag with PBS buffer $(60 \mathrm{~mL}, 12 \mathrm{mM})$ at $\mathrm{pH} 6.5$ and 7.2. The solutions were maintained at $37{ }^{\circ} \mathrm{C}$ and $3 \mathrm{~mL}$ was collected for analysis at $0,0.5,1,2,5,8,16,24,48$, and $72 \mathrm{~h}$. The Fe elements were quantified using atomic absorption spectrophotometry. Likewise, for evaluating $\mathrm{H}_{2} \mathrm{~S}, 450 \mu \mathrm{L}$ of FeS-Dox@bLf NZs (6 mM) was added into a dialysis bag with HEPES buffer $(60 \mathrm{~mL}, 12 \mathrm{mM})$ at $\mathrm{pH} 6.5$ and 7.2. Then, $2 \mathrm{~mL}$ of the solution was gathered for $\mathrm{H}_{2} \mathrm{~S}$ analysis at $0,1,2,5,10,20,30,40,50,60 \mathrm{~min} . \mathrm{H}_{2} \mathrm{~S}$ concentration was evaluated using a standard MB method based on the description of Lin et al. [33].

To investigate the possibility of in vitro drug release from NZs, the FeS-Dox@bLf NZs were incubated at $37{ }^{\circ} \mathrm{C}$ for $900 \mathrm{~min}$ in PBS at different $\mathrm{pH}$ (6.5 and 7.2). Generally, certain amounts of NZs were diffused in $10 \mathrm{~mL}$ of PBS and put in the dialysis bag (MWCO 3500). Afterwards, the bag was dialyzed against $45 \mathrm{~mL}$ of the same buffer at $120 \mathrm{rpm}$. At designated times, $6 \mathrm{~mL}$ of solution the dialysis bag was withdrawn for the investigation via absorbance at $490 \mathrm{~nm}$ and was replaced by an equal volume of the same buffer. The Dox cumulative release was assessed based on the following Eq. (1):

\section{In vitro combination therapy}

The $4 \mathrm{~T} 1$ cells were cultured at a density of $3 \times 10^{5}$ cells per well into a 96-well plate and then incubated for $12 \mathrm{~h}$ at $37^{\circ} \mathrm{C}$ with $5 \% \mathrm{CO}_{2}$. After $12 \mathrm{~h}$, the $4 \mathrm{~T} 1$ cells was treated and incubated for $24 \mathrm{~h}$ (main incubation) with different concentrations of free Dox $(5,10,15,20$, and $25 \mu \mathrm{g} / \mathrm{mL}$ ), FeS@bLf NZs and FeS-Dox@bLf NZs (12.5, $25,37.5,50$ and $62.5 \mu \mathrm{g} / \mathrm{mL}$ ) without or with laser irradiation $\left(150 \mathrm{~J} / \mathrm{cm}^{2}\right.$ fluence and $100 \mathrm{~mW} / \mathrm{cm}^{2}$ irradiance) for $7 \mathrm{~min}$ in 8th hour after main incubation. In the following, the MTT assay was performed at $570 \mathrm{~nm}$.

\section{Cellular concentration of hydroxyl radical and $\mathrm{H}_{2} \mathrm{~S}$}

To evaluate the level of hydroxyl radical in cells based on the report of LeBel et al. [34], the $4 \mathrm{~T} 1$ cells $\left(5 \times 10^{5}\right.$ cells per well) were cultured, treated by FeS@bLf NZs $(12.5,25,37.5,50$ and $62.5 \mu \mathrm{g} / \mathrm{mL})$, and incubated for $24 \mathrm{~h}$. During the incubation, the $4 \mathrm{~T} 1$ cells were treated by laser irradiation for $7 \mathrm{~min}$ in the 8th hour after incubation. Briefly, 4T1 cells were collected and loaded with $30 \mu \mathrm{M}$ the fluorogenic probe 2,7-dichlorofluorescin diacetate (DCFH-DA) at $37{ }^{\circ} \mathrm{C}$ for $30 \mathrm{~min}$ in DMEM medium without serum. The working volume DCFH-DA was supplemented proportionately according to the total cell numbers. After PBS washes, the DCF fluorescence released from DCFH-DA in the 4T1 cells was evaluated by a flow cytometer (CytoFLEX, Beckman Coulter, Brea, CA, USA) at an excitation wavelength of $500 \mathrm{~nm}$.

In order to investigate intercellular $\mathrm{H}_{2} \mathrm{~S}$ according to reports of Peng et al. [35], $5 \times 10^{5} 4 \mathrm{~T} 1$ cancer cells per well were cultured into 6-well plates for $12 \mathrm{~h}$. After incubation, Washington State Probe- $1\left(\mathrm{C}_{33} \mathrm{H}_{21} \mathrm{NO}_{6} \mathrm{~S}_{2}\right)$ $(50 \mu \mathrm{M})$ was applied as $\mathrm{H}_{2} \mathrm{~S}$ probe for $30 \mathrm{~min}$ and then treated with 12.5, 25, 37.5, 50 and $62.5 \mu \mathrm{g} / \mathrm{mL}$ of FeS@bLf without or with laser irradiation in 8th hour along with $200 \mu \mathrm{M}$ of $\mathrm{Na}_{2} \mathrm{~S}$. Afterwards, supplemented HEPES containing $100 \mu \mathrm{M}$ of CTAB (pH 7.4). After $10 \mathrm{~min}$, samples were visualized immediately by a fluorescence micro-

$$
\text { Cumulative drug release }(\%)=\frac{6 \times \sum_{\mathrm{i}-1}^{\mathrm{n}-1} \mathrm{C}_{\mathrm{i}}+\mathrm{V} \times \mathrm{C}_{\mathrm{n}}}{\text { weight of Dox on FeS@bLf }} \times 100 \text {, }
$$

where, $C_{i}$ and $C_{n}$ refer to the of Dox concentration at time $i$ and $n$, and $\mathrm{V}$ was the volume of the buffer in the drug release experiment, respectively.

\section{In vitro assays}

The 4T1 cells were seeded in DMEM medium with $10 \%$ FBS, $100 \mathrm{U} / \mathrm{mL}$ of penicillin, and $100 \mu \mathrm{g} / \mathrm{mL}$ of streptomycin and preserved in an incubator with $5 \% \mathrm{CO}_{2}$ at $37^{\circ} \mathrm{C}$ and $95 \%$ humidity. scope with a 465/515 nm and an excitation/emission filter set (ECLIPSE, TE2000-S, Nikon).

\section{Apoptosis and ROS assays}

To evaluate of apoptosis in the presence of free Dox (20 $\mu \mathrm{g} / \mathrm{mL}), \quad F e S-D o x @ b L f ~ N Z s$ and FeS-Dox@bLf $\mathrm{NZs}+$ Laser $(50 \mu \mathrm{g} / \mathrm{mL})$, flow-cytometry was used. The $4 \mathrm{~T} 1$ cells $\left(5 \times 10^{5}\right.$ cells per well) were treated with drugs and NZs with (in 8th hours of main incubation) or without laser irradiation in for $24 \mathrm{~h}$. Then, the cells were 
gathered with $3000 \mathrm{~g}$ centrifugation at $4{ }^{\circ} \mathrm{C}$ for $3 \mathrm{~min}$, and washed with PBS. Then, the $4 \mathrm{~T} 1$ cells were resuspended in $100 \mu \mathrm{L}$ per tube of containing Annexin $\mathrm{V}$ binding buffer (HEPES buffer: $0.1 \mathrm{M}, \mathrm{NaCl} 1.4 \mathrm{M}, \mathrm{CaCl}_{2} 25 \mathrm{mM}$, $\mathrm{pH}$ 7.4). In the following, $2 \mu \mathrm{L}$ of Annexin-V was added to the cells solution and retained in dark for $15 \mathrm{~min}$ at $21^{\circ} \mathrm{C}$. Afterwards, $400 \mu \mathrm{L}$ of the binding buffer and $5 \mu \mathrm{L}$ of $50 \mu \mathrm{g} / \mathrm{mL}$ propidium iodide were added to the solution and reserved in ice. Finally, samples were analysed by BD FACSCalibur Flow Cytometer.

Similar to ${ }^{\circ} \mathrm{OH}$ assay in Sect. 2.6.2, to determine intracellular ROS in the presence of free Dox $(20 \mu \mathrm{g} / \mathrm{mL})$, FeSDox@bLf NZs and FeS-Dox@bLf NZs + Laser $(50 \mu \mathrm{g} /$ $\mathrm{mL}), 5 \times 10^{5} 4 \mathrm{~T} 1$ cancerous cells per well were cultured into 6-well plate for $24 \mathrm{~h}$. Then, the fluorescent intensity based on DCF measurement was evaluated.

\section{In vivo assays}

For in vivo studies, 40 mice in 5 groups were used. For this purpose, 7-weekly female mice, weighing $25.6 \pm 1.3 \mathrm{~g}$ were kept at $25{ }^{\circ} \mathrm{C}$ with $12 \mathrm{~h}$ of light, $55 \%$ humidity and free access to water and feed. The cultured $4 \mathrm{~T} 1$ cancerous cells $\left(1 \times 10^{6}\right.$ cell $)$ according to Sect. 2.6 were injected subcutaneously $(150 \mu \mathrm{L})$ at the end of the mammary gland on the right side of the mice. After the tumors reached a size of $144.1 \pm 2.4 \mathrm{~mm}^{3}$, mice were treated 6 times, every 4 days $(0,4,8,12,16,20$ days) with free Dox $(10 \mathrm{mg} / \mathrm{kg})$ and FeS-Dox@bLf NZs $(20 \mathrm{mg} / \mathrm{kg})$ with and without laser irradiation. The amount of Dox injection in free and FeS-Dox@bLf NZs conditions was equal.

\section{Body weight and tumour size}

The mice were orderly monitored for abnormal behaviour and were weighed every four days. Also, to measure the tumor volume (TV), the mice were evaluated in each measurement by the digital Vernier Caliper (Mitutoyo, Japan) based on Eq. (2):

$$
T V\left(m m^{3}\right)=1 / 2 \times\left(\text { length } \times w i d t h^{2}\right) .
$$

Furthermore, mice were sacrificed on day 18, and the tumours were collected and weighed.

\section{Photodynamic therapy (PDT)}

For PDT assay, the tumors were illuminated every four days and $8 \mathrm{~h}$ after free drug and FeS-Dox@bLf NZs injections, through the skin surface with spot diameter of $10 \mathrm{~mm}$ for $7 \mathrm{~min}$ with light of a $150 \mathrm{~J} / \mathrm{cm}^{2}$ fluence and $100 \mathrm{~mW} / \mathrm{cm}^{2}$ irradiance by applying a diode laser. Light with a wavelength of $630 \mathrm{~nm}$ to the entire tumor was set up to prevent possible damage.

\section{Dox distribution}

For studying the Dox concentration in main organs including heart, spleen, liver, lung and breast tumor tissues, the samples were collected, washed with cold saline and dried. Then, tissues were homogenized in an acetonitrile and water (50:50) mixture for liquid-liquid phase extraction explained by Zhang et al. [36].

Fluorescent imaging was used to investigate the biodistribution of the Dox in the whole body and main organs. For this purpose, to determine the distribution of the Dox in the whole body, after $8 \mathrm{~h}$ from drug injection, the mice were anesthetized and fluorescence imaging was performed with excitation $485 \mathrm{~nm}$ and emission $590 \mathrm{~nm}$. Likewise, to image the Dox distribution in vital organs, mice were sacrificed in $8 \mathrm{~h}$ after injection and their vital organs were collected and after washing with $0.9 \% \mathrm{NaCl}$, ex vivo fluorescence was used with the same device settings.

\section{Excrete and distribution of $\mathrm{Fe}$}

In order to evaluate the concentration of excreted Fe via urine and faces, the animals were placed in metabolic glass cages. Faecal and urinary samples were collected $48 \mathrm{~h}$ and $\mathrm{Fe}$ concentration was determined on days 0 (to determine the background level), 8 and 16 days after FeS-Dox@bLf NZs administration. The amount of Fe in the samples was determined using atomic absorption spectrophotometry. Moreover, to evaluate the Fe distribution in tissues of tumor, heart, lung, spleen and liver, microwave digestion technique with mixture $\mathrm{HNO}_{3}: \mathrm{HClO}_{4}(5: 1)$ was applied. Then, $0.2 \mathrm{~g}$ of digested samples was diluted with $50 \mathrm{~mL}$ of deionized water, and finally Fe elements were measured by atomic absorption spectrophotometry.

\section{Histological assay}

For histopathological evaluation of major organs including heart, liver, spleen, lung, and tumor, the mice were sacrificed and their organs were collected at the end of experiments. Formaldehyde (10\%) was used to fix the tissue samples and then continued by passage and embedding in paraffin. To perform the hematoxylin and eosin (H\&E) staining operation, paraffin blocks were partitioned by $3 \mu \mathrm{m}$ thickness. Slides were studied with the microscopic (Olympus microscope).

\section{Statistical analysis}

Statistical analysis was carried out with one-way ANOVA followed by least square means and statistical 
differences were measured at level of ${ }^{*} P<0.05,{ }^{* *} P<0.01$ and ${ }^{* * * *} P<0.001$.

\section{Results}

\section{FeS-Dox@bLf NZs characterization}

The morphological properties of the FeS-Dox@bLf NZs produced were initially investigated by SEM and TEM. As shown in Fig. 1A, the FeS-Dox@bLf NZs are spherical with a size of $35 \mathrm{~nm}$, and also the Lf coating covers them well. The SEM (Fig. 1A) and TEM (Fig. 1B) images show the relatively normal distribution of FeS-Dox@bLf NZs during synthesis. DLS results also show that the particle size of FeS varies from 5 to $70 \mathrm{~nm}$ with a polydispersity index (PDI) of 0.114, whereas drug loading increased the size of NPs to $7-75 \mathrm{~nm}$ with a PDI of 0.289 (Fig. 1C). Then, particle size diagram obtained by the DLS method in Fig. 1C shows that the size of FeS-Dox with dimensions of 7-75 nm in the presence of bLf increased to $10-80 \mathrm{~nm}$ with A PDI of 0.402. Therefore, the formation of bLf coating on FeS-Dox can be confirmed by increasing the particle size to at least $5 \mathrm{~nm}$. The zeta potential data in Fig. 1D indicates that the NPs have zeta potentials of $+9.1,-3.9$ and $-10.3 \mathrm{mV}$ at $\mathrm{pH} \mathrm{3,7}$ and 9, respectively, which can be part of the surface charge related to amino groups. Whereas, the zeta potential values for Fe NPs at $\mathrm{pH} 3,7$ and 9 were $-2.8,-7.1$ and -18.9 , respectively. Thus, not only the zeta potential confirms the presence of protein on Fe NPs, but also this data confirms the adequate colloidal stability of Fe NPs in biological and environmental applications. In this regard, the results of FT-IR on FeS, Dox, bLf and FeS-Dox@bLf confirm the loading of drug and bLf on the NZs (Data not shown).

The results of drug loading capacity (\%) revealed that with rising Dox concentration, despite the constant concentration of FeS@bLf NZs $(250 \mu \mathrm{g} / \mathrm{mL})$, the amount of drug loading in NZ meaningfully increases (Fig. 1E). While, the loading efficiency (\%) decreases with rising Dox concentrations. This profile proposes that the highest Dox loading in FeS@bLf NZs can be attained in the range of $100 \mu \mathrm{g} / \mathrm{mL}$ with an efficiency of $\sim 58 \%$.

The metallic NZs organize the catalysts for Fenton reaction in the blood, which can use $\mathrm{H}_{2} \mathrm{O}_{2}$ in tumors to produce $\mathrm{OH}$. In order to explore the peroxidase-like behavior of FeS-Dox@bLf NZs, after adding NZs to a solution containing $\mathrm{MB}$ and $\mathrm{H}_{2} \mathrm{O}_{2}$ for $180 \mathrm{~min}$, it was found that FeS-Dox@bLf NZs change blue color and gradually reduce the peak in the range of $600-700 \mathrm{~nm}$ by digesting MB (Fig. 2A). Color change with reducing MB confirms the time-dependent enzymatic activity of FeSDox@bLf.
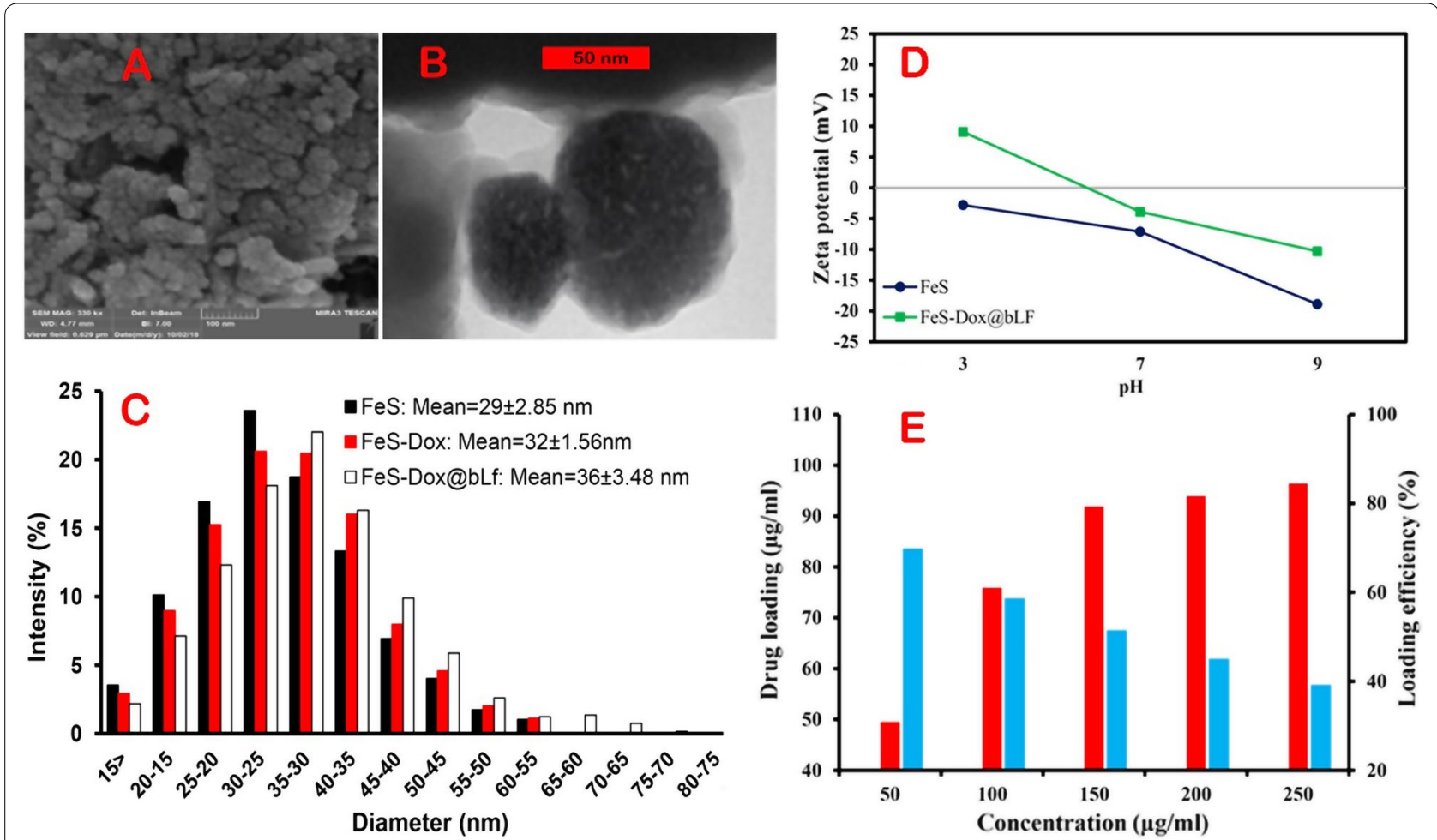

Fig. 1 SEM (A) and TEM (B) images of FeS-Dox@bLf, (C) FeS, FeS-Dox and FeS-Dox@bLf sizes distribution determined by DLS, (D) Dependence of the zeta potential on the $\mathrm{pH}$ of the solution, (E) drug loading and its efficiency 


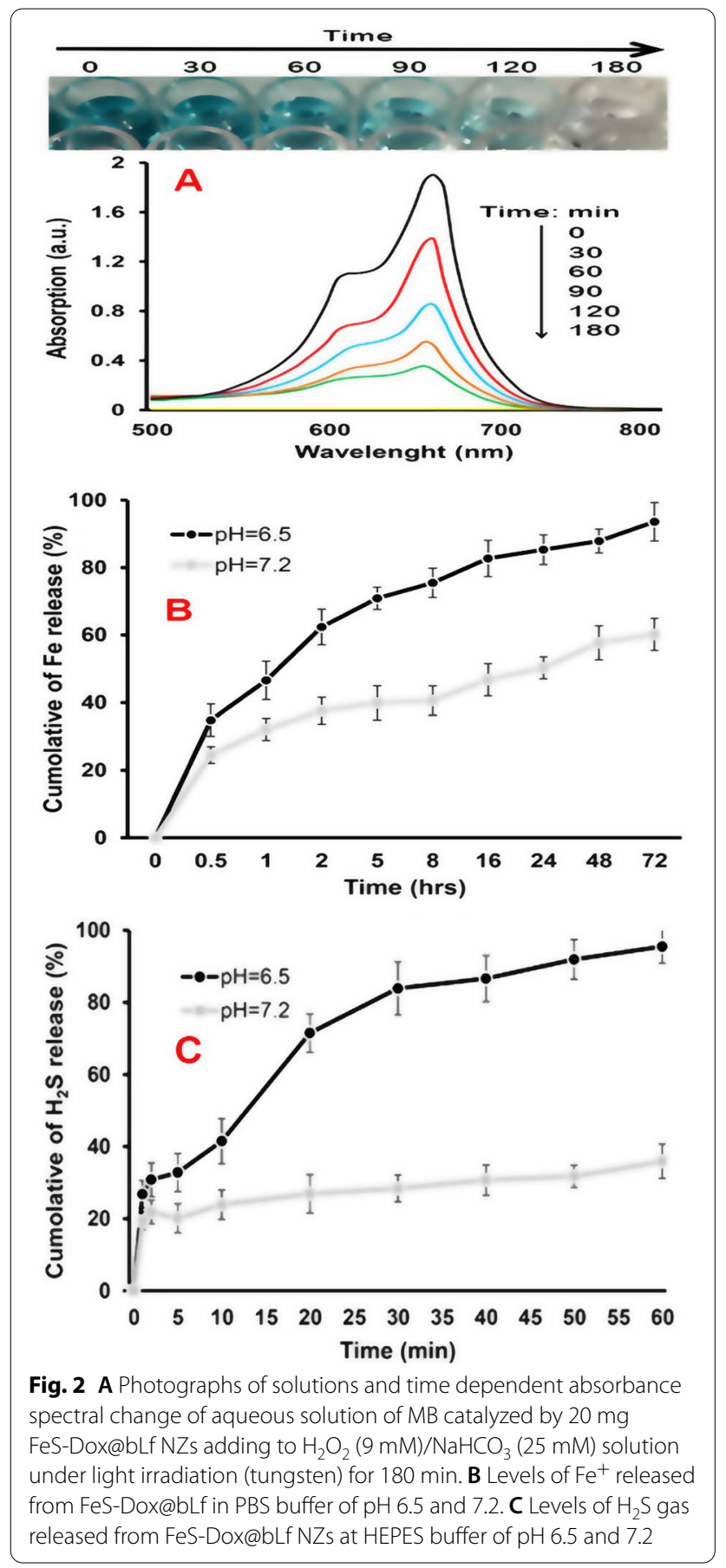

\section{$\mathrm{Fe}^{2+}, \mathrm{H}_{2} \mathrm{~S}$ and Dox release}

To evaluate the degradability of FeS-Dox@bLf NZs in blood and tumor tissue, NZs were examined in aqueous medium with pH 6.5 and 7.2. As shown in Fig. 2B, FeSDox@bLf NZs not only decompose faster in an acidic environment, but also release higher $\mathrm{Fe}^{2+}$. For example, after $8 \mathrm{~h}$, the level of $\mathrm{Fe}^{2+}$ released in the acid medium was higher than $75.5 \%$, while the level of $\mathrm{Fe}^{2+}$ released in
Table 1 Cumulative percentage of Dox release at $37{ }^{\circ} \mathrm{C}$ at different $\mathrm{pH}$

\begin{tabular}{lllll}
\hline Time $(\mathbf{m i n})$ & $\mathbf{p H ~ 6 . 5}$ & SE & $\mathbf{p H ~ 7 . 2}$ & SE \\
\hline 0 & 0 & 0 & 0 & 0 \\
6 & 15.6 & 1.78 & 5.9 & 1.15 \\
15 & 31.2 & 2.69 & 8.4 & 1.08 \\
30 & 42.1 & 2.29 & 16.3 & 1.69 \\
60 & 50.7 & 3.31 & 24.1 & 2.07 \\
90 & 55.5 & 4.35 & 28.5 & 2.15 \\
180 & 62.5 & 3.38 & 34.6 & 3.06 \\
360 & 71.1 & 5.01 & 39.7 & 3.25 \\
540 & 76.6 & 4.52 & 42.8 & 3.07 \\
720 & 80.8 & 3.69 & 44.9 & 3.76 \\
900 & 83.3 & 4.59 & 46.4 & 2.99 \\
\hline
\end{tabular}

the neutral medium was up to $40.6 \%$. This result indicates the possibility of $\mathrm{Fe}^{2+}$ release in $4 \mathrm{~T} 1$ tumor cells.

Likewise, to survey $\mathrm{H}_{2} \mathrm{~S}$ release, FeS-Dox@bLf NZs were dispersed in PBS at pH 6.5 and 7.2 for $60 \mathrm{~min}$. The results of Fig. $2 \mathrm{C}$ shows a significant increase in $\mathrm{H}_{2} \mathrm{~S}$ release by changing the acidity of the environment from neutral to acidic. As expected, FeS-Dox@bLf NZs in an acidic environment $\mathrm{H}_{2} \mathrm{~S}$ release faster and more than in a neutral medium in line with the release of $\mathrm{Fe}^{2+}$. Therefore, the release of $\mathrm{H}_{2} \mathrm{~S}$ dependent on environmental acidity by FeS-Dox@bLf NZs allows the intelligent treatment and diagnosis of cancerous tumors.

As well, by examining the release of the drug at $\mathrm{pH} 6.5$ and 7.2 at $37{ }^{\circ} \mathrm{C}$, it was determined that the Dox release from the FeS-Dox@bLf NZs based on Table 1 follows a time-dependent diffusion profile. The results indicated that the drug release rate in $\mathrm{pH}>7$ due to the function of bLf is higher than neutral (83.3 vs. 46.4 during $900 \mathrm{~min}$ ). Despite the burst release of the Dox from FeS-Dox@bLf $\mathrm{NZs}$, the rate of drug release over time is relatively constant and increasing. Above 80\% Dox release from FeSDox@bLf NZs in acidic condition is a very good potential for drug release in cancerous tissues with $\mathrm{pH}$ 6-6.6.

\section{In vitro assays}

Examination of free drug or NZs toxicity on 4T1 cancerous cells based on MTT technique revealed that free Dox, FeS@bLf, FeS-Dox@bLf NZs and FeS-Dox@bLf NZs + laser have a negative effect on 4T1 cells (Fig. 3A). Despite the high toxicity of FeS-Dox@bLf NZs on 4T1 cancer cells, the results of Fig. 3A shows that there is no significant difference between the toxicity of free Dox and FeS@bLf at different concentrations on 4T1 cancer cells. On the other hand, the use of FeS-Dox@bLf NZs + laser exposed the most toxicity for 4T1 cancerous cells compared to other groups. Overall, the results revealed that 
increasing the concentration of NZs and the free drug increased their toxicity.

Since part of the therapeutic effects of FeS-Dox@bLf NZs in this study are based on $\mathrm{H}_{2} \mathrm{~S}$ and ${ }^{\circ} \mathrm{OH}$ release, the death rate of $4 \mathrm{~T} 1$ cancerous cells death based on $\mathrm{H}_{2} \mathrm{~S}$ and ${ }^{\circ} \mathrm{OH}$ were investigated and reported in Fig. 3B, C. As seen, the most toxic effects of FeS@bLf NZs on 4T1 cells death are based on ${ }^{\circ} \mathrm{OH}$ concentration, which with increasing FeS@bLf NZs concentration, the ${ }^{\circ} \mathrm{OH}$ effect is constantly reduced and added to the $\mathrm{H}_{2} \mathrm{~S}$. On the other hand, the use of lasers on FeS@bLf NZs in this study showed that ${ }^{\circ} \mathrm{OH}$ accounts for a large proportion of cancer cell death $(" \mathrm{P} \leq 0.05)$. It is generally observed that the effects of ${ }^{\circ} \mathrm{OH}$ are much more powerful than $\mathrm{H}_{2} \mathrm{~S}$ production. However, laser irradiation of NZs increases the $\mathrm{H}_{2} \mathrm{~S}$ activity in them, which indicates an increase in $\mathrm{S}^{2-}$ release and induction of more enzymatic reactions with the released $\mathrm{Fe}^{2+}$.

In order to confirm the greater toxicity of FeS-Dox@ bLf NZs with and without laser therapy compared to free Dox in therapeutic activities, apoptosis and ROS experiments (Fig. 3D, E) demonstrated that FeS-Dox@ bLf NZs with and without laser provided the highest toxicity and cancer cell death compared to free Dox. For instance, apoptotic cells percentage in 4T1 cancer cells after $24 \mathrm{~h}$ indicated that FeS-Dox@bLf NZs, compared to the free Dox group, increased the induction of apoptosis in Q2 (early apoptosis) and Q3 (late apoptosis) quarters from 25.1 to $29.2 \%\left({ }^{* * *} \mathrm{P} \leq 0.001\right)$ and from 28.6 to $31.7 \%$ $\left({ }^{* * *} \mathrm{P} \leq 0.001\right)$, respectively. Whereas the use of laser significantly increased $4 \mathrm{~T} 1$ cells death and induced apoptosis from 29.2 to $42.8 \%(\mathrm{Q} 2)$ and from 31.7 to $33.4 \%$ (Q3). In this regard, our results in Fig. 3E confirmed the toxicity of FeS-Dox@bLf NZs compared to the free Dox by increasing the intracellular ROS. It can also be seen that the ROS level in the use of laser on the platform of FeSDox@bLf NZs is almost 3.03 folds than that of the control group, 1.84 times that of free Dox and 1.35 folds than that of FeS-Dox@bLf NZs.

\section{In vivo assays}

Because the results of in vitro method were considered favorable, cancer mice were used to evaluate the therapeutic effects of FeS-Dox@bLf NZs with or without laser irradiation in vivo condition. There was no significant difference in the weight of mice during the experimental period (Fig. 4A). However, compared to other groups, control mice had a higher rate of tumor growth. The results of Fig. 4B revealed that the integration of chemotherapy with gas therapy by FeS-Dox@bLf NZs causes a significant difference compared to the control and free Dox groups. In this regard, the use of laser irradiation on the platform of FeS-Dox@bLf NZs according to raising ROS increased the efficiency of treatment and significantly reduced the volume of breast tumors compared to free Dox and even FeS@bLf NZs. Furthermore, the results of Fig. 4C, D confirmed that the combination of chemotherapy and PDT reduces tumor volume by up to $\sim 6.2$ fold than the control group, $\sim 2.84$ fold than the free Dox and 1.77 times the FeS-Dox@bLf NZs at the end of the experimental period.

As shown in Fig. 5A, Dox accumulation by FeS-Dox@ bLf NZs was significantly increased in tumor tissue compared to free Dox. The use of nanocarriers increased drug delivery from non-target tissues to the tumor, and it significantly reduced drug levels in heart, spleen and lung tissues. Likewise, the fluorescence intensity results in Fig. 5B revealed that Dox-wide distribution throughout the whole body using the FeS-Dox@bLf NZs focuses on tumor tissue. While the distribution of free Dox throughout the body is more widespread. On the other hand, the intensity of fluorescent in vital organs shows that the use of FeS-Dox@bLf NZs increases the intensity of fluorescent in tumor tissue and decreases the intensity of fluorescent in the organs of the heart and spleen (Fig. 5C). However, no significant difference in fluorescent intensity was observed in liver and lung tissue. Therefore, the use of FeS-Dox@bLf NZ can reduce the toxicity of Dox in heart tissue, which is very undesirable for the heart in chemotherapy. Overall, the results of Fig. 5 show the successful targeting of nanoplatform-based drugs.

In addition, to evaluate $\mathrm{Fe}$ of urine plus faces, the results of Fig. 6A show that the injected NZs can be excreted from the body within $24 \mathrm{~h}$, considering the amount retained in the tissues of the spleen, lungs and heart. This result therefore explains that the amount of $\mathrm{Fe}$ received from the body is excreted and the level of toxicity is greatly reduced. In the following, the results of Fig. 6B showed an increase in Fe accumulation in tumor tissue relative to the control sample.

Finally, a histological method was used to evaluate cytotoxicity in the liver, heart, lung and spleen organs.

(See figure on next page.)

Fig. 3 A Cytotoxicity test of control, laser irradiation, free Dox, FeS NZs, and FeS-Dox@bLf NZs with or without laser irradiation (LR), on 4T1 cells by MTT assay. Mortality of $4 \mathrm{~T} 1$ cancerous cells triggered by ${ }^{\circ} \mathrm{OH}$ radicals and $\mathrm{H}_{2} \mathrm{~S}$ gas after treated with FeS@bLf without (B) or with laser irradiation (LR) for 24 h (C). D Two-dimensional contour density plots of 4T1 cells obtained by flow cytometry-based assays. a: Control, b: free Dox, c: FeS-Dox@bLf NZs, and d: FeS-Dox@bLf NZs + LR. Cell necrosis and apoptosis were measured using propidium iodide (PI) and Annexin V-FITCH dyes, and (E). The effects of a: Control, free Dox, FeS-Dox@bLf NZs, and FeS-Dox@bLf NZs + LR NZs on the ROS production. Statistical differences were measured at level of ${ }^{*} P<0.05$, and ${ }^{* *} P<0.01$ 


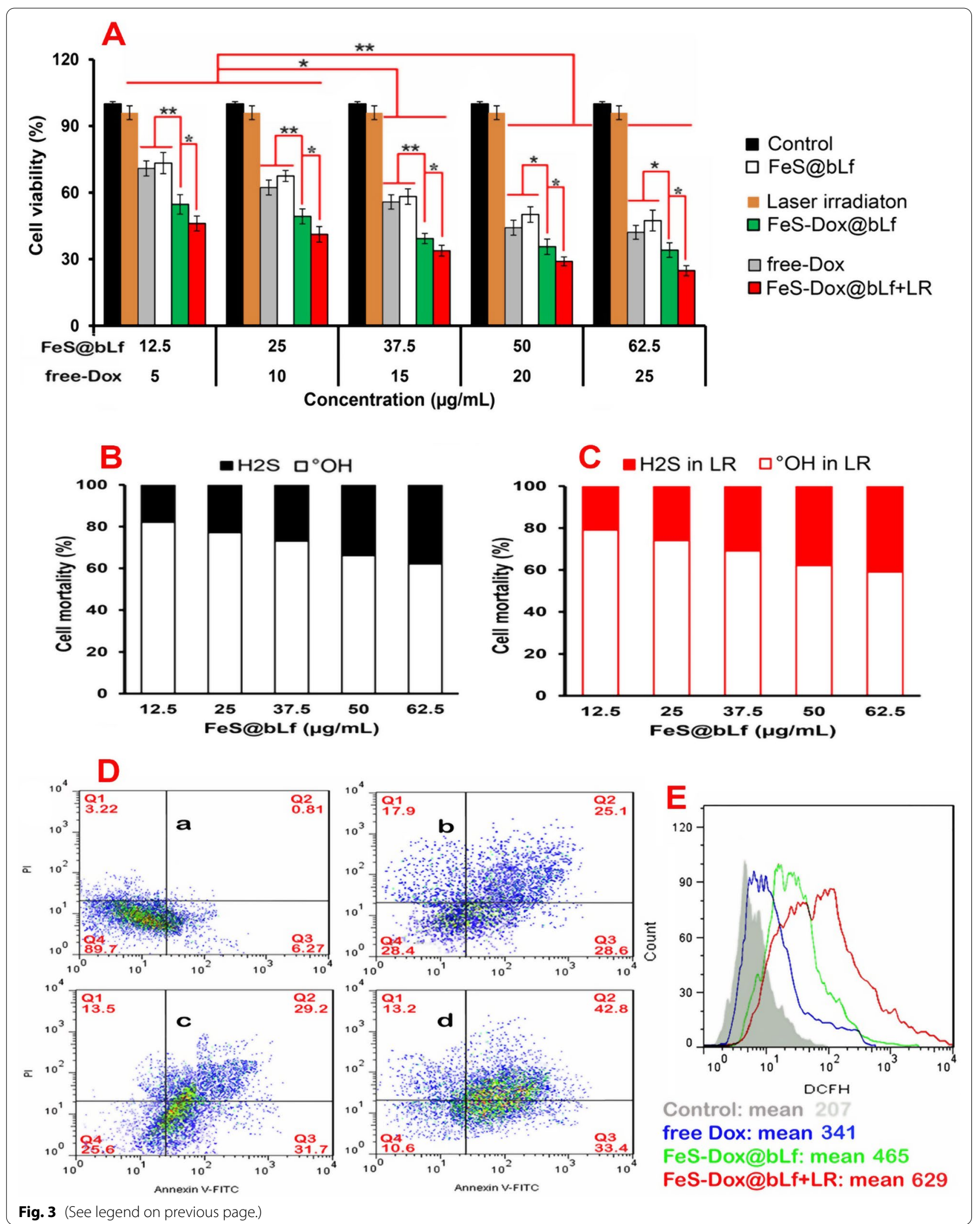



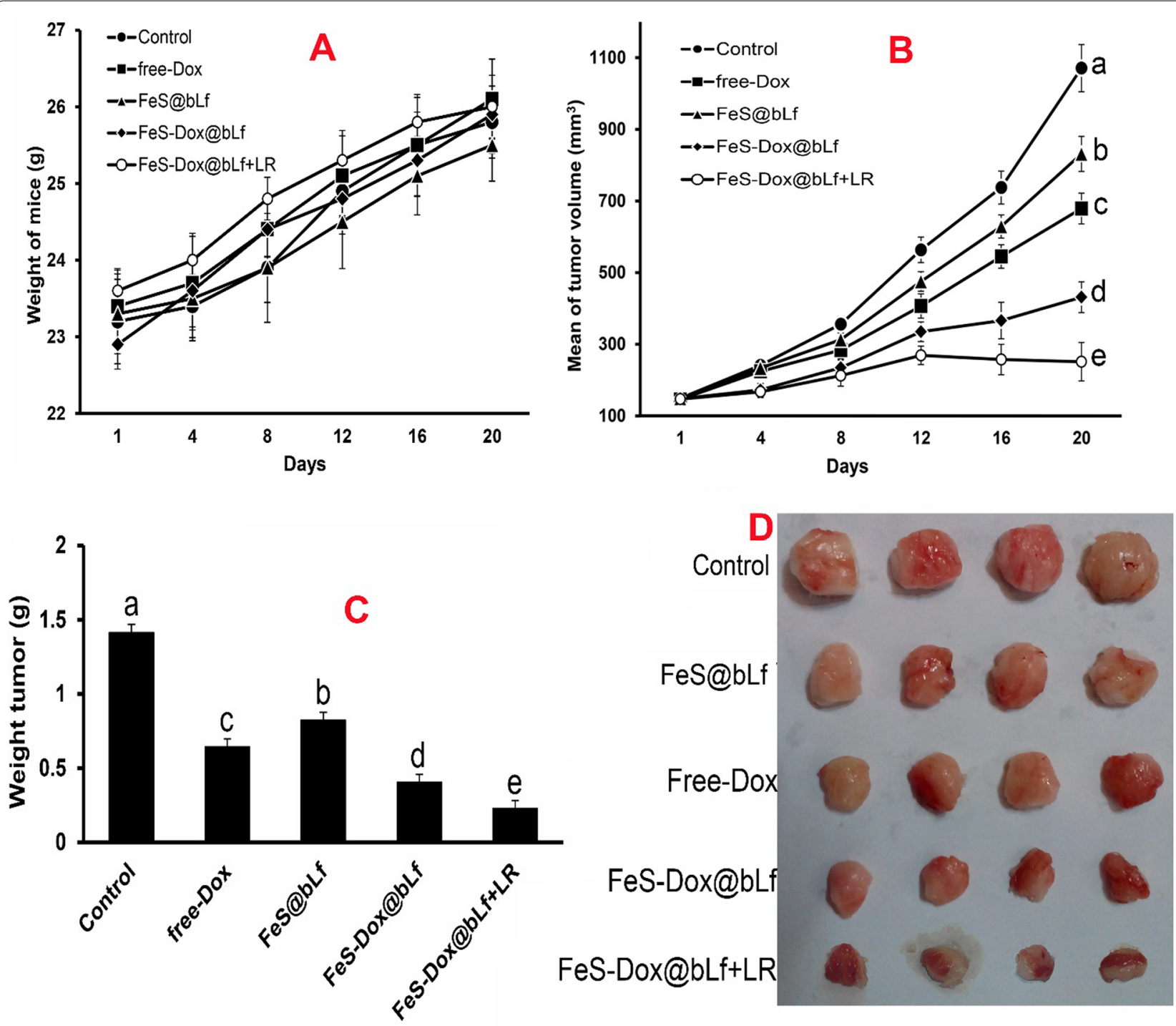

Fig. 4 A Body weight change of mice. B Tumor volume curves of different groups after treatment. C Mean weight, and (D) digital photographs of

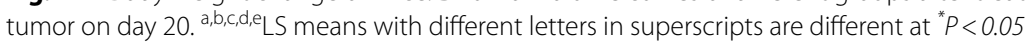

As shown in Fig. 6C, the use of free Dox causes adverse changes in heart tissue. While the use of FeS-Dox@bLf NZs with and without irradiation laser shows, the adverse effects of the drug on heart tissue are greatly reduced. It was also found that the use of different treatments did not cause significant damage to liver, spleen and lung tissue. However, analysis of tumor tissues reveals that the most important morphological changes in 4T1 tumor cells are caused by FeS-Dox@bLf NZs + Laser. However, changes in tumor tissue in the FeS-Dox@bLf NZs group versus free Dox are significant and remarkable. Staining results showed that the tumor tissue structure had disappeared in free Dox, FeS-Dox@bLf NZs with and without laser irradiation, and that some of the remaining breast cancer cells had shrunk (Fig. 6C). Typically, cancer cells appear brown with a state of necrosis or apoptosis, and live cells appear pink.

\section{Discussion}

Nowadays, the use of magnetic NPs with protein coating to target in medical activities due to the ability to synchronize an auxiliary's therapies such as PTT, PDT, with chemotherapy are highly regarded [37-39]. Therefore, to control and treat breast cancer, we designed relatively uniform FeS NZs based on the results of the SEM, TEM and DLS (Fig. 1), which was confirmed by the FT-IR results. The physicochemical properties of FeS NZs were consistent with the findings of Sathiyaraj and 

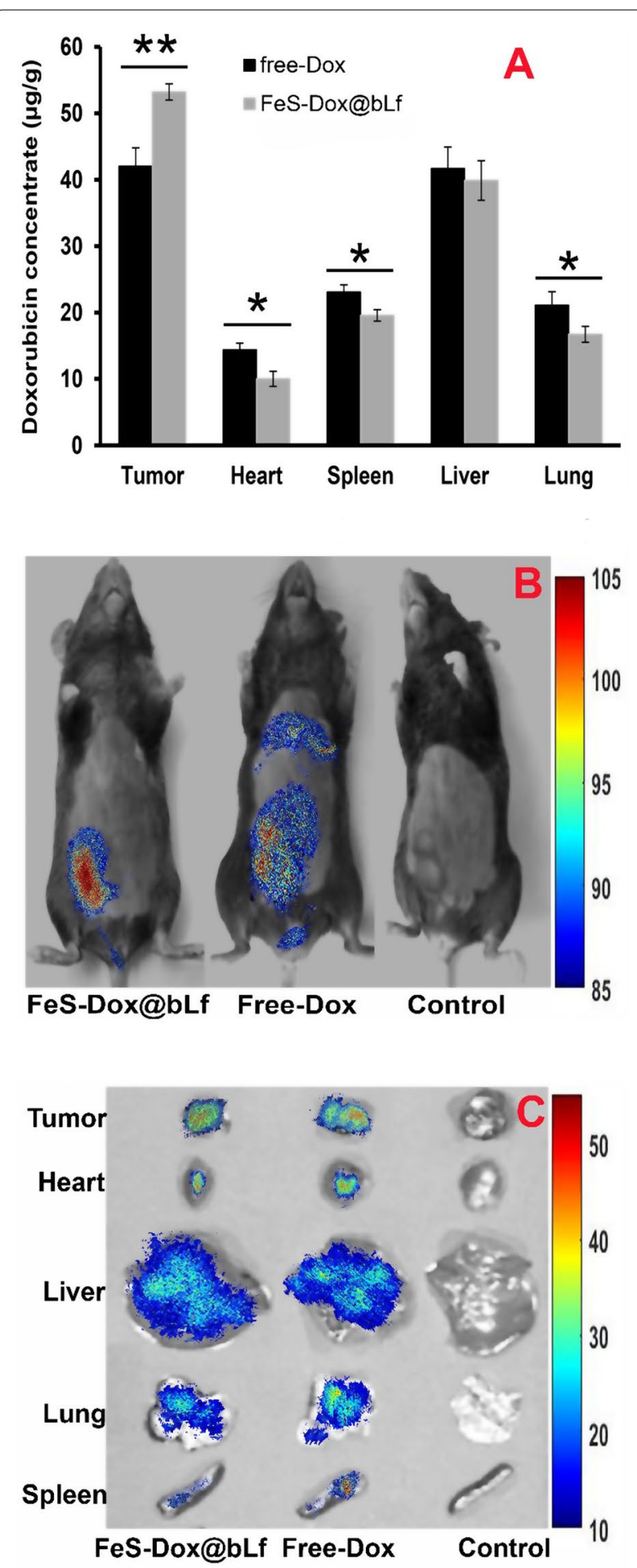

Fig. 5 A Concentration of Dox in tumor and major organs. B Biological distribution of Dox in whole body, and (C) Major organs in mice by fluorescence imaging, $8 \mathrm{~h}$ after they were i.v. injected with free Dox, and FeS-Dox@bLf NZs. Statistical differences were measured at level of ${ }^{*} P<0.05$, and ${ }^{* *} P<0.01$
Thirumaran [40] and Yang et al. [41]. On the other hand, the results of SEM, TEM and FTIR similar to the outcomes of Shankaranarayanan et al. [42] and Sharifi et al. [8] showed that bLf and Dox were loaded on FeS NZs.

Metallic NPs such as Fe, manganese (Mn), copper $(\mathrm{Cu})$, etc. as NZs are able to perform chemical reactions in biological solutions $[9,43,44]$. On the other hand, it has been confirmed that amorphous metallic NZs especially Fe NZs perform better Fenton reactions than bare NZs due to higher ionization and release of metal ions [45]. Therefore, parallel to the activities of He et al. [46] who showed that NH2-MIL-88B(Fe) NZs change the color of $\mathrm{MB}$ by producing ${ }^{\circ} \mathrm{OH}$ caused by Fenton reactions, in this study it was found that FeS@bLf NZs over time cause the digestion of $\mathrm{MB}$ in the presence of $\mathrm{H}_{2} \mathrm{O}_{2}$ and discoloration (Fig. 2A). Although the study of the MB degradation by FeS-Dox@bLF NZs in light without dark findings is a limitation in this paper, according to the findings of Molla et al. [47] who revealed that using visible light against darkness can increase the rate of MB degradation, it can be confirmed that the generated FeS-Dox@bLF NZs had a favorable catalytic effect in the decomposition of MB. Therefore, this procedure can provide a faster response for the researcher. But, in future research, the effect of FeS-Dox@bLF NZs on the decomposition of MB in light and dark can be performed to provide greater assurance of the activity of NZs to produce radicals in vivo. However, this experiment shows that the produced FeS-Dox@ bLF NZs will have good catalytic activity, especially during laser irradiation, which is relatively similar to the state of light irradiation. Digestion of MB in the presence of FeS-Dox@bLf indicates the peroxidase-like activity of NZs with the release of $\mathrm{Fe}^{2+}$, which was in agreement with the finding of Xie et al. [48]. Furthermore, the outputs of this report (Fig. 2A) similar to the results of Maji et al. [49] exhibit that the enzyme-like activities of FeS@bLf NZs are highly dependent on the duration of the presence of NZs, such as concentration, crystalline nature and particle size of NZs [50,51].

Since it has been proven that the release of metal ions increases their enzyme-like activity [50], inducing the release of $\mathrm{Fe}^{2+}$ in cancerous cells increases the possibility of therapeutic activities. In this regard, in accordance with the results of Xie et al. [48], this study revealed that FeS-Dox@bLf NZs release $\mathrm{Fe}^{2+}$ in acidic conditions in a favorable manner, which has been significantly effective in therapeutic activity (Fig. 2B). Likewise, He et al. [26] explained that MnS@BSA NZs increased enzyme-like activity by releasing $\mathrm{Mn}^{2+}$ under acidic conditions. In this regard, the $\mathrm{H}_{2} \mathrm{~S}$ release at $\mathrm{pH}$ 6.5 indicated an increase in the release of $\mathrm{Fe}^{2+}$ along with $\mathrm{S}^{2-}$ from FeS-Dox@bLf NZs (Fig. 2C). Similar to our findings, Ma et al. [52] and Kou et al. [53] explained 

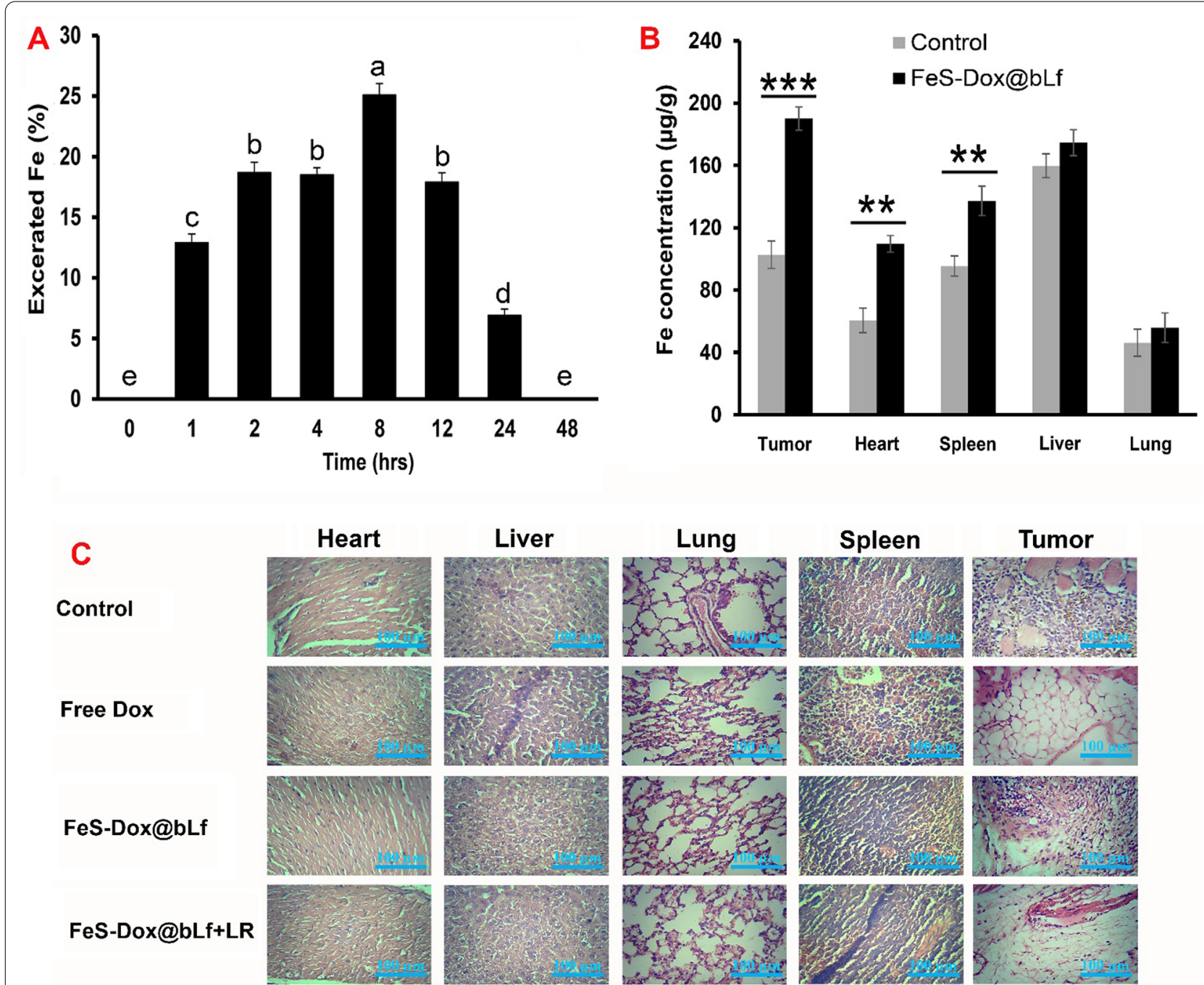

Fig. 6 A The content of Fe element in mice urine and faces after injection of FeS-Dox@bLf. B Biological distribution of Fe in major organs, and (C) Histological observation of treated breast tumor tissues and major organs include of heart, lung, liver and spleen visualized using H\&E staining. $a, b, c, d, e$ LS means with different letters in superscripts are different at ${ }^{*} P<0.05$. Statistical differences were measured at level of ${ }^{* *} P<0.01$, and ${ }^{* * *} P<0.001$

that release of $\mathrm{Cu}^{2+}$ and $\mathrm{Fe}^{2+}$ from the metal-organic framework and Fe@carboxymethyl cellulose NPs, respectively, increase gas release in acidic condition compared to neutral condition. Moreover, comparable to the results of other findings $[26,48]$, this report suggests that the use of protein coatings such as bLf delays the burst release of $\mathrm{H}_{2} \mathrm{~S}$ to further load NZs into cancer cells. Along with $\mathrm{Fe}^{2+}$ release, releasing $\mathrm{H}_{2} \mathrm{~S}$ from FeSDox@bLf NZs in acidic condition is more than neutral, which can be very important in cancer treatment activity due to the tumor microenvironmental acidic conditions. In addition to the release of $\mathrm{Fe}^{2+}$ and $\mathrm{H}_{2} \mathrm{~S}$, Dox loaded on FeS-Dox@bLf NZs will be very effective on therapeutic activity. In agreement with the results of
Singh et al. [54], Sharifi et al. [6], and Sharifi et al. [8] Table 1 shows that the release of Dox from FeS-Dox@ bLf NZs increases with decreasing environmental acidity. Analogous to the release of $\mathrm{Fe}^{2+}$ and $\mathrm{H}_{2} \mathrm{~S}$, the mechanism of release of Dox from FeS-Dox@bLf NZs into cells can be related to the effect of lysosome activity, the acidic condition of the tumor microenvironment, and endosome activity.

The toxic effects of FeS-Dox@bLf NZs with and without laser irradiation in Fig. 3A indicated that their negative effects on $4 \mathrm{~T} 1$ cancer cells are dose-dependent. This finding, together with the results of the effect of $\mathrm{NZs}$ on the increase of ${ }^{\circ} \mathrm{OH}$ and $\mathrm{H}_{2} \mathrm{~S}$ through $\mathrm{Fe}^{2+}$ catalytic activity (Fig. 3B), are in agreement with the results 
of Xie et al. [48] and Xiao et al. [55], which generally all point to the induction of apoptosis via ROS with intracellular biological changes such as DNA damage and mitochondrial dysfunction [56]. Although the lethal level of $\mathrm{H}_{2} \mathrm{~S}$ on $4 \mathrm{~T} 1$ cancerous cells is less important than ${ }^{\circ} \mathrm{OH}, \mathrm{H}_{2} \mathrm{~S}$ induces apoptosis by increasing the intracellular ROS through the Fenton reaction of $\mathrm{Fe}^{2+}$ due to the cessation of catalase activity [57] and excessive accumulation of $\mathrm{H}_{2} \mathrm{O}_{2}$ [58]. Moreover, in line with the result of Chang et al. [59], this study revealed that the synergy of chemotherapy with PDT increases intracellular ROS and apoptotic cellular death.

In vivo evaluations in this study (Fig. 4) are similar to the studies of She et al. [60] and Xie et al. [48] confirming the significant effects of FeS-Dox@bLf NZs on the size and volume of breast tumors. Numerous anti-tumor activities of drug-containing Fe NPs in breast cancer have been published parallel to this report [6, 8, 61-63], which in addition to reducing drug resistance through intelligent drug delivery increased the performance of anticancer activity by synchronizing PTT or PDT. Increased performance of FeS-Dox@bLf NZs is not only related to PDT to induce apoptosis through $\mathrm{H}_{2} \mathrm{~S}$, but also the results of Fig. 5 show that increasing the load of Dox via FeS-Dox@bLf NZs on breast tumors indicates that they are more effective in treating breast cancer. Consistent with this finding, Sharifi et al. [6] and Sharifi et al. [8] showed that Dox focused more on breast cancer tissue using Fe NPs compared to the control group. However, the positive effect of using PDT on metallic NZs containing drugs in tumor therapy is similar to the finding of Fang et al. [64] who showed that the effect of gas therapy to reduce drug resistance is very significant.

Subsequently, in vivo evaluation based on the results of Fig. 5A demonstrated that Dox accumulation was significantly reduced in non-target tissues, especially in the heart, by targeting the drug with FeS-Dox@bLf NZs, which was in line with the outcomes of Tang et al. [65] and Wang et al. [66]. This reduction significantly eliminates the side effects of chemotherapy. Meanwhile, Sharifi et al. [8] explained that the use of bLf coating increases the drug loading level in breast cancer tissue by twice to three times. Lack of accumulation of Fe NPs in lung and liver tissues, and excessive increase in Fe accumulation in tumor tissue can confirm the accumulation of Dox in tumor tissue. As well, the removal of Fe NPs from the body within $48 \mathrm{~h}$ (Fig. 6A) analogous to the result of Mn rapid clearance from the body of mice described by $\mathrm{He}$ et al. [26] indicates a reduction in the severity of toxicity of the use of FeS in long-term activity. In another part of the study, comparable to the reports of Sharifi et al. [6] and Luo et al. [67], it was shown (Fig. 6C) that the synchronization of PDT with chemotherapy significantly destroys the cellular structure of breast tumors and enhances therapeutic activity.

\section{Conclusions}

In general, a new type of amorphous FeS-Dox@bLf NZs sensitive to environmental acidity was designed by a wet-chemical method that has the ability to synchronize chemotherapy and PDT to enhance $\mathrm{H}_{2} \mathrm{~S}$ production for the treatment of breast cancer. During synthesis, it was determined that FeS-Dox@bLf NZs show peroxidase-like activity in acidic condition by releasing $\mathrm{Fe}^{2+}$ and $\mathrm{S}^{2-}$ to produce ${ }^{\circ} \mathrm{OH}$ and $\mathrm{H}_{2} \mathrm{~S}$, respectively. Therefore, the use of FeS-Dox@bLf NZs in the treatment of breast cancer with relatively acidic microenvironments can be beneficial by increasing free radicals and gas. For this purpose, evaluations of intracellular ROS and their effects on apoptotic cellular death confirmed the effects of FeS-Dox@ bLf NZs for the treatment of 4T1 cancerous cells, which was enhanced by the synchronization of chemotherapy and PDT. Furthermore, FeS-Dox@bLf NZs with targeted transfer and further release of Dox on breast tumors based on the tumor microenvironment acidic condition have allowed the drug to be loaded, which causes less toxicity in other tissues, especially in the heart. In vivo evaluations in this study also revealed that FeS-Dox@bLf NZs are highly biocompatible for long-term treatments due to the removal of Fe from the body within $48 \mathrm{~h}$ and the concentration of FeS-Dox@bLf NZs on the target tissue. Overall, all the in vitro and in vivo observations determined that FeS-Dox@bLf NZs are not only successful in treating and controlling breast cancer with minimal side effects, but also it provided a clear way to synchronize different therapies such as chemotherapy, PDT, and so on.

\section{Acknowledgements \\ Not applicable.}

\section{Authors' contributions}

SN, YZ, KQ, GL, SX, QB: Conceptualization, methodology, revision; SX, QB: analysis, validation, supervision; writing. All authors read and approved the final manuscript.

\section{Funding}

The authors gratefully acknowledge Henan Medical Science and Technology Research Youth Project Co-Sponsored by the Province and Ministry in China No: SB201902020; Top Talent Fund of the Second Affiliated Hospital of Zhengzhou University, No. 2020BJRCA03; Henan Middle-Aged Youth Health Technology Innovation Talent Project No. YXKC2020059.

\section{Declarations}

Ethics approval and consent to participate

All animal use procedures were carried out in accordance with the Regulations of Experimental Animal Administration issued by the State Committee of Science and Technology of the People's Republic of China, with the approval of the Ethics Committee in our University. 


\section{Consent for publication}

All authors read and approve the final manuscript.

\section{Availability of data and materials}

The datasets used and analysed during the current study are available from the corresponding author on reasonable request.

\section{Competing interests}

The authors declare that they have no competing interests.

\section{Author details}

'Department of Breast Surgery, Guangxi Medical University Cancer Hospital, Nanning 530000, China. ${ }^{2}$ Department of Breast Surgery, Harbin Medical University Cancer Hospital, 150 haping Road, Nangang District, Harbin 150000, China. ${ }^{3}$ Department of Anesthesiology, The Second Affiliated Hospital of Zhengzhou University, Zhengzhou, People's Republic of China.

Received: 15 July 2021 Accepted: 1 September 2021 Published online: 27 October 2021

\section{References}

1. Fang X, Cao J, Shen A. Advances in anti-breast cancer drugs and the application of nano-drug delivery systems in breast cancer therapy. J Drug Deliv Sci Technol. 2020;2020:101662.

2. Sharifi M, Hasan A, Attar F, Taghizadeh A, Falahati M. Development of point-of-care nanobiosensors for breast cancers diagnosis. Talanta. 2020;217:121091.

3. Ma X, Wang Y, Liu X-L, Ma H, Li G, Li Y, Gao F, Peng M, Fan HM, Liang X-J. $\mathrm{Fe}_{3} \mathrm{O}_{4}-\mathrm{Pd}$ Janus nanoparticles with amplified dual-mode hyperthermia and enhanced ROS generation for breast cancer treatment. Nanoscale Horizons. 2019:4:1450-9.

4. Khan S, Sharifi M, Bloukh SH, Edis Z, Siddique R, Falahati M. In vivo guiding inorganic nanozymes for biosensing and therapeutic potential in cancer, inflammation and microbial infections. Talanta. 2021;224:121805.

5. Choi WJ, Kim Y, Cha JH, Shin HJ, Chae EY, Yoon GY, Kim HH. Correlation between magnetic resonance imaging and the level of tumor-infiltrating lymphocytes in patients with estrogen receptor-negative HER2-positive breast cancer. Acta Radiol. 2020;61:3-10.

6. Sharifi M, Jafari S, Hasan A, Paray BA, Gong G, Zheng Y, Falahati M. Antimetastatic activity of lactoferrin-coated mesoporous maghemite nanoparticles in breast cancer enabled by combination therapy. ACS Biomater Sci Eng. 2020:6:3574-84.

7. Hou H, Huang X, Wei G, Xu F, Wang Y, Zhou S. Fenton reaction-assisted photodynamic therapy for cancer with multifunctional magnetic nanoparticles. ACS Appl Mater Interfaces. 2019;11:29579-92.

8. Sharifi M, Hasan A, Nanakali NMQ, Salihi A, Qadir FA, Muhammad HA, Shekha MS, Aziz FM, Amen KM, Najafi F, et al. Combined chemo-magnetic field-photothermal breast cancer therapy based on porous magnetite nanospheres. Sci Rep. 2020;10:5925

9. Sharifi M, Hosseinali SH, Yousefvand P, Salihi A, Shekha MS, Aziz FM, JouyaTalaei A, Hasan A, Falahati M. Gold nanozyme: biosensing and therapeutic activities. Mater Sci Eng C. 2020;108:110422.

10. Sharifi M, Hosseinali SH, Saboury AA, Szegezdi E, Falahati M. Involvement of planned cell death of necroptosis in cancer treatment by nanomaterials: recent advances and future perspectives. J Control Release. 2019;299:121-37.

11. Maharjan A, Dikshit PK, Gupta A, Kim BS. Catalytic activity of magnetic iron oxide nanoparticles for hydrogen peroxide decomposition: optimization and characterization. J Chem Technol Biotechnol. 2020;95:2495.

12. Pal S, Jana NR. Pharmacologic vitamin C-based cell therapy via iron oxide nanoparticle-induced intracellular Fenton reaction. ACS Appl Nano Mater. 2020:3:1683-92.

13. He $Y$-J, Liu $X-Y$, Xing $L$, Wan $X$, Chang $X$, Jiang $H$-L. Fenton reactionindependent ferroptosis therapy via Glutathione and iron redox couple sequentially triggered lipid peroxide generator. Biomaterials. 2020:2020:119911.
14. Li M, Wang X, Lu S, He C, Wang C, Wang L, Wang X, Ge P, Song D. Erastin triggers autophagic death of breast cancer cells by increasing intracellular iron levels. Oncol Lett. 2020;20:1-1.

15. Nakamura T, Naguro I, Ichijo H. Iron homeostasis and iron-regulated ROS in cell death, senescence and human diseases. Biochim Biophys Acta (BBA) Gen Sub. 2019;1863:1398-409.

16. Zhao M-X, Wen J-L, Wang L, Wang X-P, Chen T-S. Intracellular catalase activity instead of glutathione level dominates the resistance of cells to reactive oxygen species. Cell Stress Chaperones. 2019;24:609-19.

17. Zhang M-L, Wu H-T, Chen W-J, Xu Y, Ye Q-Q, Shen J-X, Liu J. Involvement of glutathione peroxidases in the occurrence and development of breast cancers. J Transl Med. 2020;18:1-11.

18. Yang L, Schoenfisch MH. Nitric oxide-releasing hyperbranched polyaminoglycosides for antibacterial therapy. ACS Appl Bio Mater. 2018;1:1066-73.

19. Zhang Y, Tan S, Xu J, Wang T. Hydrogen therapy in cardiovascular and metabolic diseases: from bench to bedside. Cell Physiol Biochem. 2018:47:1-10.

20. Pearson-Smith JN, Patel M. Antioxidant drug therapy as a neuroprotective countermeasure of nerve agent toxicity. Neurobiol Dis. 2020;133:104457.

21. Zhang P, Li Y, Tang Y, Shen H, Li J, Yi Z, Ke Q, Xu H. Copper-based metalorganic framework as a controllable nitric oxide-releasing vehicle for enhanced diabetic wound healing. ACS Appl Mater Interfaces. 2020;12:18319-31.

22. Li S, Liu R, Jiang X, Qiu Y, Song X, Huang G, Fu N, Lin L, Song J, Chen X. Near-infrared light-triggered sulfur dioxide gas therapy of cancer. ACS Nano. 2019:13:2103-13.

23. Khan S, Sharifi M, Hasan A, Attar F, Edis Z, Bai Q, Derakhshankhah H, Falahati M. Magnetic nanocatalysts as multifunctional platforms in cancer therapy through the synthesis of anticancer drugs and facilitated Fenton reaction. J Adv Res. 2020:30:171.

24. Cao X, Ding L, Xie Z-Z, Yang Y, Whiteman M, Moore PK, Bian J-S. A review of hydrogen sulfide synthesis, metabolism, and measurement: is modulation of hydrogen sulfide a novel therapeutic for cancer? Antioxidants Redox Signal. 2019;31:1-38.

25. Li J, Li X, Yuan Y, Wang Q, Xie L, Dai Y, Wang W, Li L, Lu X, Fan Q. Efficient polysulfide-based nanotheranostics for triple-negative breast cancer: ratiometric photoacoustics monitored tumor microenvironment-initiated H2S therapy. Small. 2020;16:2002939.

26. He T, Qin X, Jiang C, Jiang D, Lei S, Lin J, Zhu W-G, Qu J, Huang P. Tumor $\mathrm{pH}$-responsive metastable-phase manganese sulfide nanotheranostics for traceable hydrogen sulfide gas therapy primed chemodynamic therapy. Theranostics. 2020;10:2453.

27. Corpas FJ, Barroso JB, González-Gordo S, Muñoz-Vargas MA, Palma JM Hydrogen sulfide: a novel component in Arabidopsis peroxisomes which triggers catalase inhibition. J Integr Plant Biol. 2019;61:871-83.

28. Wei T, Xiaojun X, Peilong C. Magnoflorine improves sensitivity to doxorubicin (DOX) of breast cancer cells via inducing apoptosis and autophagy through AKT/mTOR and p38 signaling pathways. Biomed Pharmacother. 2020;121:109139.

29. Zhao Y, Alakhova DY, Zhao X, Band V, Batrakova EV, Kabanov AV. Eradication of cancer stem cells in triple negative breast cancer using doxorubicin/pluronic polymeric micelles. Nanomed Nanotechnol Biol Med. 2020;24:102124.

30. Xinyong $C$, Zhiyi Z, Lang H, Peng $Y$, Xiaocheng W, Ping Z, Liang S. The role of toll-like receptors in myocardial toxicity induced by doxorubicin. Immunol Lett. 2020;217:56-64.

31. Zhang M, Asghar S, Tian C, Hu Z, Ping Q, Chen Z, Shao F, Xiao Y. Lactoferrin/phenylboronic acid-functionalized hyaluronic acid nanogels loading doxorubicin hydrochloride for targeting glioma. Carbohydr Polym. 2020;2020:117194.

32. Kondapi AK. Targeting cancer with lactoferrin nanoparticles: recent advances. Nanomedicine. 2020;15:2071-83.

33. Lin W-C, Huang C-C, Lin S-J, Li M-J, Chang Y, Lin Y-J, Wan W-L, Shih P-C, Sung $\mathrm{H}-\mathrm{W}$. In situ depot comprising phase-change materials that can sustainably release a gasotransmitter $\mathrm{H} 2 \mathrm{~S}$ to treat diabetic wounds. Biomaterials. 2017;145:1-8.

34. LeBel CP, Ischiropoulos H, Bondy SC. Evaluation of the probe $2^{\prime}$, $7^{\prime}$-dichlorofluorescin as an indicator of reactive oxygen species formation and oxidative stress. Chem Res Toxicol. 1992;5:227-31. 
35. Peng B, Chen W, Liu C, Rosser EW, Pacheco A, Zhao Y, Aguilar HC, Xian M. Fluorescent probes based on nucleophilic substitution-cyclization for hydrogen sulfide detection and bioimaging. Chemistry (Weinheim an der Bergstrasse, Germany). 2014;20:1010-6.

36. Zhang W, Shi Y, Chen Y, Yu S, Hao J, Luo J, Sha X, Fang X. Enhanced antitumor efficacy by paclitaxel-loaded pluronic P123/F127 mixed micelles against non-small cell lung cancer based on passive tumor targeting and modulation of drug resistance. Eur J Pharm Biopharm. 2010;75:341-53.

37. Chizenga EP, Abrahamse H. Nanotechnology in modern photodynamic therapy of cancer: a review of cellular resistance patterns affecting the therapeutic response. Pharmaceutics. 2020;12:632.

38. Sharifi M, Attar F, Saboury AA, Akhtari K, Hooshmand N, Hasan A, El-Sayed M, Falahati M. Plasmonic gold nanoparticles: optical manipulation, imaging, drug delivery and therapy. J Control Release. 2019;311-312:170-89.

39. Sun M, Duan Y, Ma Y, Zhang Q. Cancer cell-erythrocyte hybrid membrane coated gold nanocages for near infrared light-activated photothermal/ radio/chemotherapy of breast cancer. Int J Nanomed. 2020;15:6749.

40. Sathiyaraj E, Thirumaran S. Structural, morphological and optical properties of iron sulfide, cobalt sulfide, copper sulfide, zinc sulfide and copperiron sulfide nanoparticles synthesized from single source precursors. Chem Phys Lett. 2020;739:136972.

41. Yang W, Xiang C, Xu Y, Chen S, Zeng W, Liu K, Jin X, Zhou X, Zhang B. Albumin-constrained large-scale synthesis of renal clearable ferrous sulfide quantum dots for T1-Weighted MR imaging and phototheranostics of tumors. Biomaterials. 2020;255:120186.

42. Shankaranarayanan JS, Kanwar JR, Abd AL-Juhaishi AJ, Kanwar RK. Doxorubicin conjugated to immunomodulatory anticancer lactoferrin displays improved cytotoxicity overcoming prostate cancer chemo resistance and inhibits tumour development in TRAMP mice. Sci Rep. 2016;6:1-16.

43. Zhang Y, Wang F, Liu C, Wang Z, Kang L, Huang Y, Dong K, Ren J, Qu X. Nanozyme decorated metal-organic frameworks for enhanced photodynamic therapy. ACS Nano. 2018;12:651-61.

44. Falahati M, Attar F, Sharifi M, Saboury AA, Salihi A, Aziz FM, Kostova I, Burda C, Priecel P, Lopez-Sanchez JA. Gold nanomaterials as key suppliers in biological and chemical sensing, catalysis, and medicine. Biochim Biophys Acta (BBA) Gen Subj. 2019;1864:129435.

45. Zhang C, Bu W, Ni D, Zhang S, Li Q, Yao Z, Zhang J, Yao H, Wang Z, Shi J. Synthesis of iron nanometallic glasses and their application in cancer therapy by a localized Fenton reaction. Angew Chem Int Ed. 2016:55:2101-6.

46. He J, Zhang $Y$, Zhang $X$, Huang $Y$. Highly efficient Fenton and enzymemimetic activities of $\mathrm{NH} 2-\mathrm{MIL}-88 \mathrm{~B}(\mathrm{Fe})$ metal organic framework for methylene blue degradation. Sci Rep. 2018;8:5159.

47. Molla A, Sahu M, Hussain S. Under dark and visible light: fast degradation of methylene blue in the presence of $\mathrm{Ag}-\mathrm{In}-\mathrm{Ni}-\mathrm{S}$ nanocomposites. J Mater Chem A. 2015;3:15616-25.

48. Xie C, Cen D, Ren Z, Wang Y, Wu Y, Li X, Han G, Cai X. FeS@ BSA nanoclusters to enable H2S-amplified ROS-based therapy with MRI guidance. Adv Sci. 2020;7:1903512.

49. Maji SK, Dutta AK, Biswas P, Srivastava DN, Paul P, Mondal A, Adhikary B. Synthesis and characterization of FeS nanoparticles obtained from a dithiocarboxylate precursor complex and their photocatalytic, electrocatalytic and biomimic peroxidase behavior. Appl Catal A. 2012;419:170-7.

50. Chen W, Li S, Wang J, Sun K, Si Y. Metal and metal-oxide nanozymes: bioenzymatic characteristics, catalytic mechanism, and eco-environmental applications. Nanoscale. 2019;11:15783-93.

51. Fu S, Wang S, Zhang X, Qi A, Liu Z, Yu X, Chen C, Li L. Structural effect of $\mathrm{Fe}_{3} \mathrm{O}_{4}$ nanoparticles on peroxidase-like activity for cancer therapy. Colloids Surf B. 2017;154:239-45.

52. Ma Y, Li X, Li A, Yang P, Zhang C, Tang B. H2S-activable MOF nanoparticle photosensitizer for effective photodynamic therapy against cancer with controllable singlet-oxygen release. Angew Chem. 2017;129:13940-4.
53. Kou Z, Zhao P, Wang Z, Jin Z, Chen L, Su B-L, He Q. Acid-responsive $\mathrm{H} 2$-releasing Fe nanoparticles for safe and effective cancer therapy. J Mater Chem B. 2019;7:2759-65.

54. Singh N, Nayak J, Sahoo SK, Kumar R. Glutathione conjugated superparamagnetic $\mathrm{Fe}_{3} \mathrm{O}_{4}$-Au core shell nanoparticles for $\mathrm{pH}$ controlled release of DOX. Mater Sci Eng C. 2019;100:453-65.

55. Xiao S, Lu Y, Feng M, Dong M, Cao Z, Zhang X, Chen Y, Liu J. Multifunctional FeS2 theranostic nanoparticles for photothermal-enhanced chemodynamic/photodynamic cancer therapy and photoacoustic imaging. Chem Eng J. 2020;2020:125294.

56. Xiao AY, Maynard MR, Piett CG, Nagel ZD, Alexander JS, Kevil CG, Berridge MV, Pattillo CB, Rosen LR, Miriyala S, Harrison L. Sodium sulfide selectively induces oxidative stress, DNA damage, and mitochondrial dysfunction and radiosensitizes glioblastoma (GBM) cells. Redox Biol. 2019;26:101220.

57. Shaikh S, Younis M, Rehman FU, Jiang H, Wang X. Specific oxide nanoclusters enhance intracellular reactive oxygen species for cancer-targeted therapy. Langmuir. 2020;36:9472-80.

58. Wan X, Song L, Pan W, Zhong H, Li N, Tang B. Tumor-targeted cascade nanoreactor based on metal-organic frameworks for synergistic ferroptosis-starvation anticancer therapy. ACS Nano. 2020;14:11017-28.

59. Chang Y, Cheng Y, Feng Y, Jian H, Wang L, Ma X, Li X, Zhang H. Resonance energy transfer-promoted photothermal and photodynamic performance of gold-copper sulfide yolk-shell nanoparticles for chemophototherapy of cancer. Nano Lett. 2018;18:886-97.

60. She D, Peng S, Liu L, Huang H, Zheng Y, Lu Y, Geng D, Yin B. Biomimic FeS2 nanodrug with hypothermal photothermal effect by clinical approved NIR-II light for augmented chemodynamic therapy. Chem Eng J. 2020;400:125933.

61. Zou Y, Li D, Wang Y, Ouyang Z, Peng Y, Tomás H, Xia J, Rodrigues JO, Shen $M$, Shi X. Polyethylenimine nanogels incorporated with ultrasmall iron oxide nanoparticles and doxorubicin for MR imaging-guided chemotherapy of tumors. Bioconjugate Chem. 2020;31:907-15.

62. Singh N, Millot N, Maurizi L, Lizard G, Kumar R. Taurine-conjugated mussel-inspired iron oxide nanoparticles with an elongated shape for effective delivery of doxorubicin into the tumor cells. ACS Omega. 2020;5:16165-75.

63. Popescu R, Savu D, Dorobantu I, Vasile B, Hosser H, Boldeiu A, Temelie M, Straticiuc M, lancu D, Andronescu E. Efficient uptake and retention of iron oxide-based nanoparticles in HeLa cells leads to an effective intracellular delivery of doxorubicin. Sci Rep. 2020;10:1-10.

64. Fang C, Cen D, Wang Y, Wu Y, Cai X, Li X, Han G. ZnS@ ZIF-8 core-shell nanoparticles incorporated with ICG and TPZ to enable H2S-amplified synergistic therapy. Theranostics. 2020;10:7671.

65. Tang X-I, Jing F, Lin B-I, Cui S, Yu R-t, Shen X-d, Wang T-w. pH-responsive magnetic mesoporous silica-based nanoplatform for synergistic photodynamic therapy/chemotherapy. ACS Appl Mater Interfaces. 2018:10:15001-11.

66. Wang D, Li X, Li X, Kang A, Sun L, Sun M, Yang F, Xu C. Magnetic and pH dual-responsive nanoparticles for synergistic drug-resistant breast cancer chemo/photodynamic therapy. Int J Nanomed. 2019;14:7665.

67. Luo X, Zhang J, Wu Y-P, Yang X, Kuang X-P, Li W-X, Li Y-F, He R-R, Liu M. Multifunctional HNT@Fe $\mathrm{O}_{4} @ P P y @ D O X$ nanoplatform for effective chemo-photothermal combination therapy of breast cancer with MR imaging. ACS Biomater Sci Eng. 2020;6:3361-74.

\section{Publisher's Note}

Springer Nature remains neutral with regard to jurisdictional claims in published maps and institutional affiliations. 